\title{
Global Oral Health Issues - Panorama Among Dental Students In Shimla- Himachal Pradesh- India
}

Shailee Fotedar ${ }^{1}$

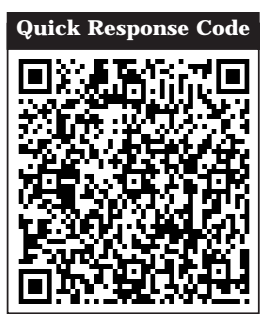

doi: $10.5866 / 2016.8 .10075$

${ }^{1}$ Asst. Professor

Dept. of Public Health Dentistry

H.P Govt. Dental College

Shimla, India

\section{Article Info:}

Received: April 13, 2016

Review Completed: May 11, 2016

Accepted: J une 10, 2016

Available Online: September, 2016 (www.nacd.in)

(C) NAD, 2016 - All rights reserved

\section{Email for correspondence:}

drfotedar@rediffmail.com

\begin{abstract}
:
Objectives: The objectives of the study were to investigate the perspective of dental students about the global oral health issues in Shimla, Himachal Pradesh- India.

Methods: A cross sectional questionnaire study was conducted among the dental students in the H.P Government Dental College, Shimla, India. A modified oral health information questionnaire (GOHIQ) consisting of 15 close-ended items was used for data collection from 3rd year, 4rth year and internship students. The data was analysed by SPSS package 16.

Results: The response rate of the study was $94.7 \%$. About $82 \%$ of the students reported that they were not aware about global oral health status. $92.3 \%$ percent of surveyed students stated that they would consider volunteering their dental skills. Only $9.8 \%$ of the surveyed students were able to identify that basic package of oral health care was created by World Health Organization. None of the surveyed students could correctly answer the question about "the three components of BPOC" as OUT, AFT, and ART. When asked for need on global oral health course $96.7 \%$ of the surveyed students reported the need for global oral health course.

Conclusion: The findings of this study indicate a gap between the knowledge of students on global oral health issues and need for global oral health course among dental students in Shimla- I ndia.
\end{abstract}

Key words: Global Oral Health, Basic package of oral care, dental curriculum and dental volunteer.

\section{INTRODUCTION:}

Oral health is an important component of general health and a determinant factor for quality of life. Despite the recognition of oral health as a human right, indi-viduals throughout the world, particularly the poor and socially disadvantaged in developing countries, suffer greatly from oral disease. ${ }^{1}$ Among the condi-tions they face are caries, gingivitis and periodontal disease, tooth loss, oral cancer, HIV-AIDS-related oral disease, facial gangrene (Noma), dental erosion, dental trauma, and dental fluorosis. ${ }^{1-3}$ Worldwide, oral disease is the 4rth most expensive diseases to treat; Dental caries affects most adults and $60-90 \%$ of school children, leading to millions of lost school days each year, and it remains one of the most common chronic diseases; periodontitis is a major cause of tooth loss in adults gl obally and oral cancer is the eighth most common cancer and most costly cancer to treat. With oral infection has been associated with issues ranging from pre-term birth and low birth weight 
to heart diseases, it may be an important contributing factor of several preventable disease. ${ }^{4}$

The burden of oral disease may be linked to any of these factors like poverty, illiteracy, poor oral hygiene, lack of oral health education. ${ }^{5}$ A part from this, persistent inequalities in access to oral health care with inadequate dental materials, drugs, instruments, and equipment are equally responsible. ${ }^{6,7}$ Although there are more than one million practicing dentists, worldwide, their unequal geographic distribution results in oversupply in some wealthy urban areas. Globally, roughly only $60 \%$ of the population worldwide enjoys access to proper oral health care, with coverage ranging from $21.2 \%$ in Burkino Faso to $94.3 \%$ in Slovakia. Between countries the density of qualified dentists varies from one dentist per 560 people in Crotia to one dentist per 1278,446 people in Ethopia; and the distribution within the counties strongly varies. ${ }^{4}$

In view of the burden of oral diseases, there has been a strong international aid response to public health emergencies and oral health disparities in developing countries. ${ }^{8,9}$ Many of the dental nongovernmental organizations (NGOs) and volunteers have contributed to remedying global oral health disparities. ${ }^{10,11}$ The activities of these groups included service provision, education and training, technical assistance and community development. The major limitations were inadequate services and non-sustainability. ${ }^{12}$

The WHO Collaborating Centre at the University of Nijmegen in the Netherlands has worked within primary oral health care principles to create an affordable and sustainable commu-nity service called the basic package of oral care (BPOC). ${ }^{13}$ The $\mathrm{BPOC}$ is designed to work with minimum resources for maximum effect and does not require a dental drill or electricity. The BPOC can be tailored specifically to meet the needs of a community. Most significant is the fact that a dentist trained in BPOC can train local ancillary medical and dental personnel to become BPOC-proficient. ${ }^{14}$ These local non-dentist BPOC-trained individuals can then become the primary resource for oral health promotion.

This community service is not a formally recognized competency for a general dentist in most of the coun-tries in the world including North America. The revised com-petencies for the predoctoral dental school cur-riculum endorsed in
March 2008 by the American Dental Education Association (ADEA) areintended to definethe entrylevel professional capacities of the general dentist. However, this document nei-ther has any mention of community service, nor regarding provision of care to the underserved communities or populations under the domain of professionalism. ${ }^{15}$

However, Global oral health course has been introduced in some devel oped countries of the world, but the same has not been introduced in india - one of the nations which has highest number of dental institutions in the world. So, the present study was conducted to investigate the outlook of dental students about global oral health issues in Shimla, Himachal Pradesh, India.

\section{Materials and Methods}

The present cross sectional questionnaire study was conducted among the dental students in the H.P Government Dental College, Shimla, Himachal Pradesh, India. Ethical approval to conduct the survey was obtained from the Head of the Institution i.e. Government Dental College and Hospital, Shimla.

The dental curriculum in India consists of 5 years of education of which 2 years course is dedicated to basic (Preclinical) education and 3 years to clinical education. So, only the students exposed to clinical dental education were included in the study. All the $3^{\text {rd }}$ year, 4rth year and interns were informed about the study during March 2014. There were total of 94 students in $3^{\text {rd }}$ year, 4 rth year and internship.

A self-administrated questionnaire consisting of 15 cl ose-ended items was used for data col-lection. The questionnaire was distributed to $3^{\text {rd }}$ and $4^{\text {rth }}$ year students after their scheduled lecture. The questionnaires were distributed to interns in their respective departments. All thestudents were given fifteen minutes to fill the questionnaire before collecting back. The questionnaire was a modification of the global oral health information questionnaire (GOHIQ). The original GOHIQ consisted of 5 sets of questions but the present questionnaire was modified to 15 questions to broaden the scope. ${ }^{16}$ Additional questions were regarding their present knowledge of global oral health status, about international volunteerism and ethics and development of oral health goals.

The validity of the survey questions can be 
assumed given that the questions had been used previously. ${ }^{16-18}$ The questionnaire was pretested by conducting a pilot study with 5 students from each year in or der to assure that the students understood the questions and wereableto answer them without help.

The data was analyzed using the Statistical Package for the Social Sciences (SPSS I nc., Chicago, $\mathrm{IL}$, version 16 for windows).

\section{Results:}

All together there were 96 students in $3^{\text {rd }}$ year, 4 rth year and internship. Out of 96 students 91 responded which means the response rate was $94.7 \%$. Out of 91 responded students there were 21(23.07) males and 70(76.9) females. The distribution of subjects is shown in table 1.

Most of the students $82.4 \%$ (75) reported that they were not aware about global oral health status and $84.6 \%$ (77) reported that were not aware about oral health care systems of devel oped and developing countries. $92.3 \%$ (84) percent of surveyed students stated that they would consider volunteering their dental skills and expertise as a senior dental student or future dentist in an international setting or developing country, whereas 7.7\% (7) stated that they would not. $47.2 \%$ (43) of the surveyed students reported that they felt that the dental education had "not at all" prepared them to serve the underserved population, $17.7 \%(16)$ reported that they were somewhat prepared, 35.1\%(32) reported that they were moderately prepared and no one reported that he was greatly prepared.

When asked about the aims of a volunteer dentist $60.4 \%$ (55) reported "to improve the oral health status of the population served"; $35.1 \%$ (32) reported "to increase availability of health care on a continuing basis through sustained activities "and $4.3 \%$ (4) reported the option "both the above."

When asked about the cultural competence of dentists, 64.8\% (59) reported "to respect the culture of host community; $28.7 \%$ (26) reported "try to adapt" and $6.5 \%$ (6) reported "both the above."For the question on global health ethics, $8.6 \%$ (8) correctly reported the option " both the above"

$52.7 \%(48)$ students could correctly identify equity, community participation, appropriate technology and inter-sectoral approach as components of primary health care. Only 9.8\% (9) of the surveyed students were able to identify that basic package of oral health care (BPOC) was created by World Health Organization. None of the surveyed students could correctly answer the question about "the three components of BPOC" as OUT (oral urgent treatment), AFT (Affordable Fluoride tooth paste, and ART (Atraumatic Restorative Treatment).

None of the surveyed students could correctly identify FDI as the world's main dental/oral health NGO whose mandate is to 'bring together the world of dentistry. Only $7.7 \%$ (7) students could report correctly IADR as the world's main dental body whose mandate is to promote dental and oral health research.

When asked for need on global oral health course $96.7 \%$ (88) of the surveyed students reported the need for global oral health course.

\section{Discussion}

All over the world, population growth and ageing have led to an increasing need for oral healthcare. Furthermore, a gradual increase in awareness as well as mass media exposure has led to an increased demand for oral health. At present, neither the need nor demand is fully met on a global level, despitethe fact that oral health is a basic right and its contribution is fundamental to a good quality of life and overall health. ${ }^{4}$

So, the time is now right for developing a new model for oral health care, by shifting the focus of our model from (i) a traditionally curative, mostly pathogenic model to a more salutogenic approach, which concentrates on prevention and promotion of good oral health and (ii) from a rather exclusive to a more inclusive approach, which takes into consideration all the stakeholders who can participate in improving the oral health of the public, we will be able to position our profession at the forefront of a global movement towards optimised health through good oral health.

To better equip members of the oral healthcare workforce for the challenges at present we need to consider some modification in our educational curricula to take into account a stronger focus on prevention of oral disease in communities or vulnerable populations.

In the present study, $82.4 \%$ reported that they were not aware about global oral health status and 
84.6\% reported that were not aware about oral health care systems of developed and developing countries which is slightly less than $99.2 \%$ as reported by Singh $\mathrm{A}$ among dental students in central India. ${ }^{17}$

$92.3 \%$ percent of surveyed students stated that they would consider volunteering their dental skills and expertise as a senior dental student or future dentist in an international setting or developing country which is in line with the findings by Karim A (84\%), Abhinav S (87\%) and Omoigberai BB(100\%). ${ }^{16-18} 47.2 \%$ of the surveyed students reported that they felt that the dental education had "not at all" prepared them to serve the underserved population.

When asked about the aims of a volunteer dentist, $4.3 \%$ could rightly answer "to improve the oral health status of the population served" and "to increase availability of health care on a continuing basis through sustained activities. Similarly only $6.5 \%$ of the students could correctly answer question about cultural aspects on international health. The question on global health ethics was correctly answered by $8.6 \%$.

The present study showed that $9.8 \%$ of the surveyed students identified that basic package of oral health care was created by World Health Organization which was less than as reported by Singh A(27\%) and Omoigberai BB (20.5\%) but higher than as reported by Karim $\mathrm{A}(0 \%) .{ }^{16-18} \mathrm{~N}$ one of the surveyed students could correctly answer the question about "the three components of BPOC" as OUT, AFT, and ART which is in line with Karim A and Omoigberai BB.

In 1982, World Dental Federation (FDI) and WHO developed the global goal for oral health for theyear 2000. About a decadeago WHO, jointly with the Federation Dentaire Internationale (FDI) and the International Association for Dental Research (IADR), formulated goals for oral health by the year 2020. These specific goals may assist in the development of effective oral health programs, targeted to improve the health of those people most in need of care. ${ }^{19-21}$ I $n$ the present study no one could recognize FDI as the world's main dental/oral health NGO whose mandate is to "bring together the world of dentistry as was also reported by Karim A. ${ }^{16}$ Only $7.7 \%$ students could report correctly IADR as the world's main dental body whose mandate is to promote dental and oral health research which is somewhat similar to the findings of Omoigberai BB. ${ }^{18}$

The results of the study suggest that the majority of the surveyed dental students at this dental school expressed a desire to volunteer their profes-sional services in international settings. However, none of the surveyed students knew about WHO'S BPOC or FDI's role in global oral health. This means there is a gap between gl obal oral health policy and interventions set out by WHO and FDI and awareness of this policy and global oral health issues among dental students in Shimla, Himachal Pradesh, India.

Hence creating a predoctoral global oral health course that includes the principles of $\mathrm{POHC}$ and BPOC, at all levels could reinforce the concept that care to the underserved is integral to the profession and it is an ethical responsibility. Instilling a public purpose in dental students is as important as teaching them about the newest clini-cal techniques or latest high tech dental software. A sense of awareness can be created that oral health education, promotion, and service delivery exist in unique parallel formulas that can be applied depend-ing on the circumstances. ${ }^{22}$ As such, global oral health education teaches the value of alternatives and does not cripple students to believe that there is only one ideal treatment modality for all situations. This will enable students as future dental professionals to feel confident and skillful regardless of their environment; it may even inspire some to become international dental volunteers, dental NGO leaders, or oral health policy advocates. Educating students about global oral health issues includes them in the reality of global oral health disparities and facilitates the belief that they can affect change within and beyond their immediate community. ${ }^{23,24}$

Encouraging results have been found after a curriculum change in Peru and Vetnam. ${ }^{25,26}$ Such programs challenge dental students to value dental public health issues and provide a real-istic understanding of prevailing oral health problems faced by the international community. So it is her eby recommended to develop a systematic curriculum for global oral health course in dental schools of both devel oped and developing countries. The curriculum elements could include global burden of oral diseases, oral health care delivery systems of industrialized and emerging economies, primary oral health carestrategies, the role of WHO and FDI 
Table 1: Distribution of subjects according to study year.

\begin{tabular}{|l|cc|cc|cc|l|l|}
\hline Gender & \multicolumn{2}{|l|}{$\mathbf{3}^{\text {rd }}$ Year } & \multicolumn{2}{|l|}{$\mathbf{4}^{\text {rth }}$ Year } & \multicolumn{2}{|l|}{ Internship } & \multicolumn{2}{|l|}{ Total } \\
\hline & $\mathrm{N}$ & $\%$ & $\mathrm{~N}$ & $\%$ & $\mathrm{~N}$ & $\%$ & $\mathrm{~N}$ & $\%$ \\
\hline Males & 8 & $23.5 \%$ & 7 & $33.4 \%$ & 6 & 15.8 & 21 & 23.07 \\
\hline Females & 24 & $76.5 \%$ & 14 & $66.6 \%$ & 32 & 84.2 & 70 & 76.93 \\
\hline Total & 32 & $100 \%$ & 21 & $100 \%$ & 38 & $100 \%$ & 91 & $100 \%$ \\
& & & & & & & &
\end{tabular}

Table 2: Response to Global oral health information questionnaire:

\begin{tabular}{|c|c|c|c|}
\hline Question & Response & Number & $\%$ \\
\hline Q1..Do you know the global oral health status? & $\begin{array}{l}\text { Yes } \\
\text { No }\end{array}$ & $\begin{array}{l}16 \\
75\end{array}$ & $\begin{array}{l}17.6 \\
82.4\end{array}$ \\
\hline $\begin{array}{l}\text { Q2. Are you aware about oral health care systems } \\
\text { of developed and developing countries? }\end{array}$ & $\begin{array}{l}\text { Yes } \\
\text { No }\end{array}$ & $\begin{array}{l}14 \\
77\end{array}$ & $\begin{array}{l}15.4 \\
84.6\end{array}$ \\
\hline $\begin{array}{l}\text { Q3. Would you like to serve the under-served } \\
\text { countries as a volunteer dentist? }\end{array}$ & $\begin{array}{l}\text { Yes } \\
\text { No }\end{array}$ & $\begin{array}{l}84 \\
7\end{array}$ & $\begin{array}{l}92.3 \\
7.7\end{array}$ \\
\hline $\begin{array}{l}\text { Q4. Do you have sufficient training to serve the } \\
\text { under -served population? }\end{array}$ & $\begin{array}{l}\text { Not at all } \\
\text { Somewhat } \\
\text { Moderately } \\
\text { Greatly }\end{array}$ & $\begin{array}{r}3 \\
16 \\
32 \\
0\end{array}$ & $\begin{array}{l}47.3 \\
17.6 \\
35.2 \\
0.00\end{array}$ \\
\hline $\begin{array}{l}\text { Q5. As a volunteer dentist your aim should be: } \\
\text { a) to improve the oral health status of the } \\
\text { population served. } \\
\text { b) to increase availability of health care on a } \\
\text { continuing basis through sustained activities. } \\
\text { c)None of the above } \\
\text { d)Both the above. }\end{array}$ & $\begin{array}{l}\text { Correct Answer } \\
\text { Incorrect Answer }\end{array}$ & 87 & $\begin{array}{l}4.3 \\
95.7\end{array}$ \\
\hline
\end{tabular}




\begin{tabular}{|c|c|c|c|}
\hline $\begin{array}{l}\text { Q6. As a volunteer dentist one should: } \\
\text { a)Respect the culture of the } \\
\text { host community } \\
\text { b) Try to adapt as much as possible. } \\
\text { c) one of the above } \\
\text { d) Both of the above }\end{array}$ & $\begin{array}{l}\text { Correct Answer } \\
\text { Incorrect answer }\end{array}$ & 85 & 93.4 \\
\hline $\begin{array}{l}\text { Q7. The global health ethics addresses: } \\
\text { a)the need for structured programs between } \\
\text { partners, } \\
\text { b)the goal of mutual and reciprocal benefit, } \\
\text { c) None of the above } \\
\text { d)Both the above }\end{array}$ & $\begin{array}{l}\text { Correct Answer } \\
\text { Incorrect Answer }\end{array}$ & 89 & 2.2 \\
\hline $\begin{array}{l}\text { Q8. Are you aware of primary oral health care } \\
\text { strategies? }\end{array}$ & $\begin{array}{l}\text { Yes } \\
\text { No }\end{array}$ & $\begin{array}{l}54 \\
37\end{array}$ & $\begin{array}{l}59.3 \\
40.7\end{array}$ \\
\hline $\begin{array}{l}\text { Q9. Primary health care strategy includes: } \\
\begin{array}{lll}\text { a) Equity, b)Prevention } & \text { c) Community } \\
\text { participation, d) Appropriate technology, } \\
\text { e) Intersectorial approach } & \text { f) Don't know }\end{array}\end{array}$ & $\begin{array}{l}\text { Correct Answer } \\
\text { Incorrect answer } \\
\text { Don't know }\end{array}$ & 26 & $\begin{array}{l}52.7 \\
28.6 \\
18.7\end{array}$ \\
\hline $\begin{array}{l}\text { Q10. Who developed global oral health goals for } \\
2020 \text { ? } \\
\begin{array}{llll}\text { a)WHO b) FDI } & \text { c) IADR } & \text { d) All of them }\end{array}\end{array}$ & $\begin{array}{l}\text { Correct Answer } \\
\text { Incorrect answer } \\
\text { Don't know }\end{array}$ & $\begin{array}{l}79 \\
5\end{array}$ & $\begin{array}{r}7.7 \\
86.8 \\
5.5\end{array}$ \\
\hline $\begin{array}{l}\text { Q11. Who created Basic Package of Oral } \\
\text { Care (BPOC)? }\end{array}$ & $\begin{array}{l}\text { a) FDI } \\
\text { b) WHO } \\
\text { c) IADR } \\
\text { d) Don't know }\end{array}$ & $\begin{array}{r}33 \\
9 \\
25 \\
24\end{array}$ & $\begin{array}{r}36.3 \\
9.9 \\
27.5 \\
26.4\end{array}$ \\
\hline $\begin{array}{l}\text { Q12. BPOC includes: } \\
\begin{array}{ll}\text { a) Oral treatment b) Oral urgent treatment, } \\
\text { c) Pit \& fissure sealants, d) ART, }\end{array}\end{array}$ & $\begin{array}{l}\text { Correct Answer } \\
\text { Incorrect answer }\end{array}$ & O & 0.0 \\
\hline $\begin{array}{l}\text { e) Affordable fluoride tooth paste } \\
\text { f) Affordable tooth brush? } \\
\text { g) Don't know }\end{array}$ & Don't know & 8 & 8.8 \\
\hline $\begin{array}{l}\text { Q13. The world's main dental body whose } \\
\text { mandate is to bring together the world of } \\
\text { dentistry. }\end{array}$ & $\begin{array}{l}\text { a) FDI } \\
\text { b) WHO } \\
\text { c) IADR } \\
\text { d) Don't know }\end{array}$ & $\begin{array}{l}0 \\
71 \\
11 \\
9\end{array}$ & $\begin{array}{r}0.0 \\
78.0 \\
12.1 \\
9.9\end{array}$ \\
\hline $\begin{array}{l}\text { Q14. The world's main dental body whose } \\
\text { mandate is to promote oral and dental health } \\
\text { research is: }\end{array}$ & $\begin{array}{l}\text { a) FDI } \\
\text { b) WHO } \\
\text { c) IADR } \\
\text { d) Don't know }\end{array}$ & $\begin{array}{r}19 \\
39 \\
7 \\
26\end{array}$ & $\begin{array}{r}20.9 \\
42.9 \\
7.7 \\
28.6\end{array}$ \\
\hline $\begin{array}{l}\text { Q15. Is there a need for global oral health course } \\
\text { among dental students? }\end{array}$ & $\begin{array}{l}\text { Yes } \\
\text { No }\end{array}$ & $\begin{array}{c}88 \\
3\end{array}$ & $\begin{array}{r}96.7 \\
3.3\end{array}$ \\
\hline
\end{tabular}


in international health, the role of humanitarian organizations and global dental volunteers, BPOC as a competent form of oral health care delivery, dental ethics, with topics on sustainability, global health ethics, and addressing the needs of underserved populations, and cultural competence in addressing international oral health issues.

\section{Conclusion}

So, it can be concluded from the present study, that the outlook about global oral health issues among dental students in Shimla is low. All the students expressed a desire to volunteer their professional services in international settings. However, few students knew about the WHO and FDI global goal for oral health as well as the role of IADR and FDI on global oral health. None of the student was able to identify correctly the three components of BPOC. The results suggest that there is a gap between global oral health policy and interventions set out by WHO and FDI and awareness of this policy, interventions and global oral health issues among dental students in Shimla, India.

\section{References:}

1. Petersen PE, Bourgeois D, Ogawa H, Estupinan-Day S. The global burden of oral diseases and risks to oral health. Bull World Health Organ 2005; 83:661-669.

2. Petersen PE. Priorities for research for oral health in the 21st century: the approach of the WHO Global Oral Health Programme. Community Dent Health 2005; 22:71-74.

3. Yee R, Sheiham A. The burden of restorative dental treatment for children in third world countries. Int Dent J 2002; 52:1-9.

4. Michael G, Orlando MS, Gerhard KS, Tao X, Gilberto P, David MW, et al., FDI Vision 2020: Shaping the future of oral health. Int Dent J 2012; 62:278-291.

5. Auluck A. Oral health of poor people in rural areas of developing countries. J Can Dent Assoc 2005; 71:753-757.

6. World Health Organisation.The World Oral Health Report, 2003 Geneva.

7. Helderman VP, Mikx F, Truin GJ, Hoang TH, Pham HL. Workforce requirements for a primary oral health care system. Int Dent J 2000; 50:371-377

8. Hobdell M, Petersen PE, Clarkson J, J ohnson N. Global goals for oral health 2020. Int Dent J 2003; 53:285-258.

9. Benzian $\mathrm{H}$, van Palenstein Helderman W. Dental charity work - Does it really help? Br Dent J 2006; 201:413.
10. Hobdell MH. Taxonomy of volunteering - Humanitarian missions: What they can do and what it involves. Dev Dent 2003; 1:16-20.

11. Dickson M, Dickson GG. Volunteering: Beyond an act of charity. J Can Dent Assoc 2005; 71:865-869.

12. Benzian H, Gelbier S. Dental aid organisations: Baseline data about their reality today. Int Dent J 2002; 52:309-314.

13. Mikx F. Caring for oral needs through the basic package of oral care. Developing Dent 2003; 1:5-8.

14. van Palenstein Helderman W, Benzian H. Implementation of a basic package of oral care: towards a reorientation of dental NGOs and their volunteers. Int Dent J 2006; 56:1-5.

15. Watt RG. Emerging theories into the social determinants of health: implications for oral health promotion. Community Dent Oral Epidemiol 2002; 30:241-247.

16. Karim A, Mascarenhas AK, Dharamsi S. A global oral health course: Isn't it time? J Dent Educ 2008; 72:1238-1246.

17. Singh A, Purohit B. Global oral health course: Perception among dental students in central India. Eur J Dent.2012; 6:295-301.

18. Omoigberai BB, Emeka Danielson Odai. A survey of dental students on global oral health issues in Nigeria. JISPCD 2014; (4):17-21.

19. Hobdell M, Petersen PE, Clarkson J , J ohnson N. Global goals for oral health 2020. Int Dent J 2003; 53:285-288.

20. Peterson PE: The World Oral Health Report 2003: Continuous improvement of oral health in the 21 st century -The approach of the WHO global oral health programme. Community Dent Oral Epidemiol 2003; 31:3-23.

21. World Health Organization. World Health Report, 2006. Available from: http://www.who.int/whr/2006/whr06 en.pdf. [Last accessed on 2014 Apr 27]

22. American Dental Education Association. Position paper: statement on the roles and responsibilities of academic dental institutions in improving the oral health status of all Americans (as revised by the 2004 House of Delegates). J Dent Educ 2008; 72(7):841-848.

23. Huynh-VoL,Rosenbloom J M, Aslanyan G, Leake J L. Investigating the potential for students to provide den-tal services in community settings. J Can Dent Assoc 2002; 68(7):408-411.

24. Kerr AR, Changrani J G, Garry FM, Cruz GD. An aca-demic dental center grapples with oral cancer disparities: current collaboration and future opportunities. J Dent Educ 2004; 68(5):531-41.

25. Bernabe E, Bernal J B, Beltran-Neira RJ . A model of dental public health teaching at the undergraduate level in Peru. J Dent Educ 2006; 70(8):875-883.

26. van Palenstein Helderman W, Mikx F, Truin GJ . Workforce requirements for a primary oral health care system. Int Dent J 2000; 50:371-377.

\section{Gain quick access to our journal online View our journal at www.nacd.in}

